\title{
The effect of galling aphids feeding on photosynthesis photochemistry of elm trees (Ulmus sp.)
}

\author{
K. KMIEĆ ${ }^{*,+}$, K. RUBINOWSKA ${ }^{* *}$, W. MICHAŁEK ${ }^{* *}$, and H. SYTYKIEWICZ*** \\ Department of Entomology, University of Life Sciences in Lublin, Leszczyńskiego 7, 20-069 Lublin, Poland* \\ Department of Plant Physiology, University of Life Sciences in Lublin, Akademicka 15, 20-950 Lublin, Poland ${ }^{* *}$ \\ Department of Biochemistry and Molecular Biology, Siedlce University of Natural Sciences and Humanities, Prusa 12, \\ 08-110 Siedlce, Poland ${ }^{* * *}$
}

\begin{abstract}
Changes of chlorophyll (Chl) $a$ fluorescence and photosynthetic pigment contents were analysed in galled leaves (visibly damaged and undamaged parts) and intact leaves. The values of minimal fluorescence of the dark-adapted state, maximal quantum yield of PSII photochemistry, effective quantum yield of PSII photochemical conversion, and photochemical quenching coefficient decreased in Ulmus pumila L. leaves galled by Tetraneura ulmi (L.) and in U. glabra Huds. galled by Eriosoma ulmi (L.). Colopha compressa (Koch.) feeding affected these parameters only in damaged parts of $U$. laevis Pall. galled leaves. The increasing number of T. ulmi galls progressively decreased photosynthetic performance. In gall tissues of all analysed aphid species, the lowest photosynthetic pigment content was found, indicating that the photosynthetic capacity must have been low in galls. Significant reduction of $\mathrm{Chl}$ and carotenoid contents were observed in damaged and undamaged portions of galled leaves only in the case of T. ulmi feeding.
\end{abstract}

Additional key words: biotic stress; Eriosomatinae, fluorescence parameters; host plant response.

\section{Introduction}

The galling aphids (Aphididae: Eriosomatinae) inhabiting elms in Poland are heteroecious species (Wojciechowski et al. 2015). In the spring, the first instar of fundatrix (stem mother) hatches from eggs laid in bark crevices of trees. After hatching, the larva migrates to developing leaves, finds a suitable site, and starts the galling process. In the gall, adult fundatrix gives birth parthenogenetically to offsprings that develop into winged aphids. The galls of Colopha compressa (Koch.) and Tetraneura ulmi (L.) are closed and localised on the upper side of the leaf blade, while Eriosoma ulmi (L.) forms open, leaf-roll pseudogalls (Álvarez et al. 2013, Blackman and Eastop 2017). Only two generations of aphids develop in the galls (Urban 2003, Wool 2004, Kmieć and Kot 2007, Suzuki et al. 2009). It is commonly believed that gall inducers have the ability to control and program host plant growth in order to produce new structures by utilising behavioural, mechanical, chemical, and genetic manipulations to their own benefit. Galling insects use new structures as nutrition sources and shelters (Larson and Whitham 1991, El-Akkad 2004, Huang et al. 2014a). Galls are considered extended phenotypes of aphids, because the shape and size of the gall is determined by the inducing aphid (Álvarez et al. 2013). With few exceptions, only the stem mother can induce the gall, although her offspring is genetically identical (Wool 2004). At present, the stimulus that allows the fundatrix to interfere with developmental processes in the host plant and induce the gall is still unknown. Creation of novel cells by insect probably requires reprogramming of the plant genome. The induction of the gall causes a change in the design of the plant tissue; hypertrophy of vascular bundles, specifically, of the phloem is observed (Harris et al. 2010, Álvarez et al. 2013). Furthermore, the occurrence of galls causes various disruptions in host plant physiology, such as changes in $\mathrm{pH}$ and polarity, nutrient composition, carbon transport and allocation, enzyme

Received 30 June 2017, accepted 29 November 2017, published as online-first 13 April 2018.

${ }^{+}$Corresponding author; e-mail: katarzyna.kmiec@up.lublin.pl

Abbreviations: Car - carotenoids; $\mathrm{CF}$ - chlorophyll fluorescence; $\mathrm{Chl}$ - chlorophyll; $\mathrm{F}_{0}, \mathrm{~F}_{\mathrm{m}}$ - minimal and maximal fluorescence yield of the dark-adapted state, respectively; $\mathrm{F}_{0}{ }^{\prime}, \mathrm{F}_{\mathrm{m}}{ }^{\prime}$ - minimal and maximal fluorescence yield of the light-adapted state, respectively; $F_{s}$ - steady-state fluorescence yield; $F_{v}$ - variable fluorescence in the dark-adapted state; $F_{v} / F_{m}-$ maximal quantum yield of PSII photochemistry; $\mathrm{q}_{\mathrm{N}}$ - nonphotochemical quenching coefficient; $\mathrm{q}_{\mathrm{P}}$ - photochemical quenching coefficient; $\mathrm{Y}$ - effective quantum yield of PSII photochemical conversion; ФPSII - quantum efficiency of PSII electron transport.

Acknowledgments: This work was supported by University of Life Sciences in Lublin (Project no. OKE/DS/2 in 2013-2017). Authors thank to three anonymous reviewers for their valuable comments, which helped improve this manuscript.

(C) The Author(s). This article is published with open access at link.springer.com 
activity, $\mathrm{Chl}$ and carotenoid contents as well as alterations in secondary metabolites (El-Akkad 2004, Huang et al. 2014b).

Photosynthesis is considered one of the most important metabolic processes in plants. Among indirect effects on physiological processes, photosynthesis disruption can have the most significant influence on plant growth and performance. The magnitude of this effect on photosynthetic capacity is multifaceted, depending mostly on the type of herbivore feeding habits and the specificity of plant defence responses (Nabity et al. 2009). The photosynthetic rate can be elevated by increasing sink demand, as a result of phloem parasite feeding (Retuerto et al. 2004). Aphids drain assimilates and cause cellular damage during inserting fine stylets puncturing cell walls and injecting salivary toxins. Most of the reported functional molecules in aphid saliva are proteins that are secreted into the phloem (Elzinga et al. 2014). Galling aphids tap directly into the host phloem and feed on the nutrients moving through the host (Larson and Whitham 1997, Álvarez et al. 2013). The galls of Pemphigus betae Doane act as strong sinks, reversing normal transport patterns and inducing mature leaves to import photoassimilates produced in neighbouring leaves (Larson and Whitham 1991). However, photosynthetic rates estimated by gas-exchange measurements were significantly reduced in leaves galled by Melaphis rhois (Fitch). Furthermore, aphid galls did not significantly affect photosynthesis in the surrounding leaflets (Larson 1998). On the other hand, the galls of Caryomyia midge reduced PSII efficiency up to $14 \mathrm{~mm}$ away from the visibly affected tissue (Aldea et al. 2006).

Photosynthetic performance can be evaluated by the noninvasive $\mathrm{Chl}$ fluorescence technique, which provides information on the impact of insect feeding on photosynthesis. This method is very useful in studying adaptive mechanisms activated in plants to cope with stress (Nabity et al. 2009, Murchie and Lawson 2013). One of the key parameters provided by Chl fluorescence is quantum yield in dark-adapted leaves (ratio between variable and maximum fluorescence, $\left.F_{v} / F_{m}\right)$. This is a commonly used parameter to estimate plant response to various stresses, because it indicates direct damage to PSII

\section{Materials and methods}

Plant material and insects: The research was carried out on Ulmus glabra Huds., U. laevis Pall., and U. pumila L. trees, which were a part of urban green areas of Lublin, Poland $\left(51.24^{\circ} \mathrm{N}, 22.57^{\circ} \mathrm{S}\right)$. The climate of the area is characterized by an annual mean temperature of $7.3^{\circ} \mathrm{C}$, annual mean relative air humidity of $79 \%$, and a total rainfall of $550 \mathrm{~mm}$. During the experimental period, the weather was typical for the spring in Eastern Poland. The leaves of these elm species were galled by E. ulmi, C. compressa, and T. ulmi. Laterally compressed, cockscomb shaped, yellowish (reddish) galls of $C$. compressa are formed on the upper leaf surfaces, close to the midrib. reaction centres and alterations in the photosynthetic pigments. Changes in $\mathrm{F}_{\mathrm{v}} / \mathrm{F}_{\mathrm{m}}$ values may be misinterpreted, thus, other fluorescence parameters, e.g. $\mathrm{F}_{0}$ and $\mathrm{F}_{\mathrm{m}}$ should be also analysed. The increased $F_{0}$ and $F_{m}$ values caused by the drought stress have been found previously. Elevation in $\mathrm{F}_{0}$ could result from inhibition of PSII acceptor side, $\mathrm{Q}_{\mathrm{A}}$ reduction, and dissociation of LHCII from PSII (Bączek-Kwinta et al. 2011, Murchie and Lawson 2013). The quantum efficiency of PSII ( $\left.\Phi_{\text {PSII }}\right)$ is a particularly useful parameter, which under non-stress conditions is highly correlated with the rate of $\mathrm{CO}_{2}$ uptake in leaves and is directly associated with carbon assimilation (Nabity et al. 2012 and references therein).

Pigments are integrally related to the physiological function of leaves. Light energy is absorbed by $\mathrm{Chl}$ and transferred into the photosynthetic apparatus. Carotenoids (Car) play an accessory light-harvesting role. However, they protect the photosynthetic apparatus by quenching harmful free radicals naturally produced during photosynthesis. They also play an important role as signalling precursors during plant development under abiotic/biotic stress. Variations in pigment contents may provide information about the physiological state of leaves (Ashraf and Harris 2013). Chl loss is associated with environmental stress, and the variation in the total $\mathrm{Chl} / \mathrm{Car}$ ratio may be a good indicator of stress in plants (Netto et al. 2005).

So far, little has been published on the physiology of elm aphid galls and their effect on hosts (Gailite et al. 2005, Samsone et al. 2007, 2012; Suzuki et al. 2009, Kmieć et al. 2017). The objective of this research was to quantify the effects of feeding of three galling aphid species on photosynthesis, estimated by a Chl fluorescence method and photosynthetic pigment contents in leaves of elms growing in urban green areas. This study used two type of galls (open and closed) and different locations of true galls on the leaf in order to determine whether the alteration in photosynthesis chemistry depended on the species. We documented the course of processes in the galls, adjacent galled and ungalled tissue, and intact leaves. We also tested whether multiple aphid galls on a single leaf resulted in more pronounced effect on photosynthesis.

Visible discoloration of leaf blades below the gall is observed (Gailite et al. 2005, Kmieć et al. 2016). The galls of T. ulmi are stalked, bean shaped, smooth, and shiny. Initially they are green, mature are yellowish, mostly localised in the distal part of the leaf blade. Near each gall stalk, a part of lamina is discoloured and corrugated (Urban 2003, Kmieć et al. 2016). Both types of galls are formed by a single fundatrix (Kmieć and Kot 2007, Blackman and Eastop 2017). Pseudogalls of E. ulmi are formed by downward curling, twisting, and blistering of one lateral edge of the elm leaf; the deformed part becomes yellowish or whitish green. Galls are established 
by one or occasionally several young stem mothers (Kmieć and Kot 2010, Blackman and Eastop 2017).

In our study, the galls of C. compressa and T. ulmi were never found on the same tree. The galls of E. ulmi were found occasionally together with T. ulmi galls. Therefore, intact and galling leaves of a particular aphid species were analysed separately on different elm species according to the dominant galling aphid: U. pumila with T. ulmi, U. glabra with E. ulmi, and U. laevis with C. compressa (Kmieć and Kot 2010, Kot and Kmieć 2013, Kmieć et al. 2016). The measurements were conducted on leaves of 4-5 trees for each elm species. Owing to developmental differences of particular aphid species, systematic field observations were conducted from April. Plant material was analysed when galls were mature with larvae of the $3^{\text {rd }}$ and $4^{\text {th }}$ instar inside. For all analyses, intact leaves of a similar age (located at a similar site on the shoots and a similar canopy position) were used as a control. We did not find completely gall-free elm trees in any location. Therefore, due to aphid tendency to induce many galls on one shoot (personal observation), intact leaves were taken from the shoots without galls.

The measurements of Chl $\boldsymbol{a}$ fluorescence were performed under field conditions in situ, on sunny days with air temperatures about $20^{\circ} \mathrm{C}$, between 9:00 and 11:00 h of the local time to avoid possible effects of midday photosynthetic depression, in three combinations: (1) intact leaves, (2) damaged part of galled leaf (with visible discoloration and/or corrugation), and (3) undamaged part of galled leaf (adjacent tissue without visible damage). For each aphid species, the measurements were performed on 60 leaves (20 leaves for each treatment) in the canopy up to $2 \mathrm{~m}$ high. In the case of leaves galled by T. ulmi, the number of galls on each analysed leaf was recorded. Chl fluorescence was measured with a $P A M-2000$ fluorometer ( Walz GmbH, Germany) using the saturation pulse method (Schreiber et al. 1992). The initial fluorescence was measured after dark adaptation (leaves were shaded for about $20 \mathrm{~min}$ with manufactured clips), when all PSII reaction centres were open $\left(\mathrm{F}_{0}\right)$, and the maximum fluorescence $\left(\mathrm{F}_{\mathrm{m}}\right)$ was measured at the end of the saturating light pulse [intensity $\sim 2,800 \mu \mathrm{mol}$ (photon) $\mathrm{m}^{-2} \mathrm{~s}^{-1}$ ]. Light sufficient to drive photosynthesis [actinic light, PPFD = $1,000 \mu \mathrm{mol}$ (photon) $\mathrm{m}^{-2} \mathrm{~s}^{-1}$ ] was subsequently applied, and after $10 \mathrm{~min}$, the ground fluorescence $\left(\mathrm{F}_{\mathrm{s}}\right)$ was measured, as evidenced by the constant fluorescence levels. The maximum fluorescence at steady-state conditions $\left(\mathrm{F}_{\mathrm{m}}\right.$ ') was determined by applying pulses of saturated white light every $60 \mathrm{~s}$ when the actinic light was on. Chl fluorescence was calculated according to the following equations:

The maximum quantum yield of PSII: $\mathrm{F}_{\mathrm{v}} / \mathrm{F}_{\mathrm{m}}=$ $\left(F_{m}-F_{0}\right) / F_{m}$, where $F_{v}$ equals the fluorescence increase induced by the saturation pulse.

The effective quantum yield: $Y=\left(F_{m}{ }^{\prime}-F_{s}\right) / F_{m}$ '.

Coefficient of photochemical fluorescence quenching:
$\mathrm{q}_{\mathrm{P}}=\left[\left(\mathrm{F}_{\mathrm{m}}{ }^{\prime}-\mathrm{F}_{\mathrm{s}}\right) /\left(\mathrm{F}_{\mathrm{m}}{ }^{\prime}-\mathrm{F}_{0}{ }^{\prime}\right)\right]$.

Coefficient of nonphotochemical quenching:

$\mathrm{q}_{\mathrm{N}}=\left[\left(\mathrm{F}_{\mathrm{m}}-\mathrm{F}_{\mathrm{m}}{ }^{\prime}\right) /\left(\mathrm{F}_{\mathrm{m}}{ }^{\prime}-\mathrm{F}_{0}{ }^{\prime}\right)\right]$.

The calculation of $\mathrm{q}_{\mathrm{P}}$ and $\mathrm{q}_{\mathrm{N}}$ required the $\mathrm{F}_{0}$ ' parameter, which was experimentally obtained after a dark; red light pulse was applied to previously light-adapted leaves.

Pigment content: After Chl fluorescence measurements, the same leaves were collected for pigment analysis. The leaves were cut with scissors, kept in plastic bags, and brought to the laboratory within $1 \mathrm{~h}$ after collection. In the laboratory, the leaves were prepared for analysis. Firstly, C. compressa and T. ulmi galls were removed from the leaves using a scalpel. Subsequently, the aphids were removed from true and pseudogalls by a soft brush. Parts of the leaf blade with visible damage were cut off. The pigment content was analysed in four combinations for $C$. compressa and T. ulmi: (1) control (intact) leaves, (2) undamaged portions of galled leaves (without visible discoloration and corrugation), (3) damaged portions of galled leaves, (4) galls. Three combinations were used for E. ulmi: (1) intact leaves, (2) undamaged portions of galled leaves (without visible discoloration and corrugation), (3) pseudogalls. Fresh plant material was used for analysis. The content of pigments was determined according to the method described by Lichtenthaler and Wellburn (1983) after taking $0.5 \mathrm{~g}$ (fresh mass, FM) of leaf and $80 \%$ acetone extraction. The absorbance was measured at three wavelength $(\lambda): 470 \mathrm{~nm}$ (carotenoids), $646 \mathrm{~nm}(\mathrm{Chl} b)$, and 663 nm (Chl $a)$, using a Cecil CE 9500 spectrophotometer (Cecil Instruments, Cambridge England).

The concentration of particular pigment was calculated according to the following formulas:

$$
\begin{aligned}
& \mathrm{C}_{\mathrm{Chl} a}=12.21 \mathrm{~A}_{663}-2.81 \mathrm{~A}_{646}, \\
& \mathrm{C}_{\mathrm{Chl} b}=20.13 \mathrm{~A}_{646}-5.03 \mathrm{~A}_{663}, \\
& \mathrm{C}_{\mathrm{Car}}=\left(1,000 \mathrm{~A}_{470}-3.27 \mathrm{C}_{\mathrm{Chl} a}-104 \mathrm{C}_{\mathrm{Chl} b}\right) / 227,
\end{aligned}
$$

where $A_{\lambda}$ is the absorbance value for wavelength $\lambda$.

Next, pigments concentrations were converted into their content in the leaf fresh mass. All analyses were performed in five replicates for each treatment.

Statistics: Data distribution was tested by the KolmogorovSmirnov's test. Differences in photosynthetic parameters between tissues were examined using one-way analysis of variance $(A N O V A)$ for data with normal distribution (U. laevis with C. compressa, U. pumila with T. ulmi). The Kruskal-Wallis test, as a nonparametric alternative to $A N O V A$, was applied after the rejection of data normality for photosynthetic parameters of U. glabra with E. ulmi and pigment contents in all elm tissues. Afterwards, post-hoc pairwise comparisons of means were applied. A simple regression model was employed to examine the relationship between the number of galls and photosynthetic parameters in $U$. pumila leaves galled by $T$. ulmi. The statistical significance was set at $p \leq 0.05$. All statistical analyses were performed using Statistica 13.1 (StatSoft, Poland). 


\section{Results}

Galling-photosynthesis relationship: Feeding of all analysed galling species resulted in significant differences in the values of all photosynthetic activity indices, except for the quantum yield value for $C$. compressa (Table 1). The $F_{0}$ value was significantly affected by the galling of all analysed aphid species. This parameter showed the lowest values in damaged parts of all galled leaves and in E. ulmi pseudogalls. During aphid feeding the value of $\mathrm{F}_{0}$ obtained in pseudogalls was the most strongly reduced, to $55 \%$ of the level of respective intact leaves (Table 1). The highest level of PSII maximum quantum efficiency of all elm species was recorded in control leaves. This value was significantly reduced in both undamaged and damaged parts of galled leaves due to E. ulmi and T. ulmi feeding. The $F_{v} / F_{m}$ value in leaf tissues above the galls of C. compressa (undamaged) was similar to control leaves. However, the maximum quantum yield of PSII below the gall (damaged part) was significantly reduced by $28 \%$ (Table 1). The effective quantum yield was affected only by E. ulmi and T. ulmi feeding. The subsequent decrease of Y value from the undamaged to damaged parts of galled leaves inhabited by both aphid species was observed. For the $\mathrm{q}_{\mathrm{P}}$ coefficient, a similar pattern of changes like in the case of $F_{v} / F_{m}$ parameter, was noted. The reduction of $q_{P}$ value in the leaves galled by T. ulmi was the highest, while in those galled by $C$. compressa was the lowest one. The
$\mathrm{q}_{\mathrm{N}}$ coefficient in the damaged parts of the leaves galled by all aphid species increased compared with control leaves. The highest increase, almost 2-fold, was caused by T. ulmi feeding. The $\mathrm{q}_{\mathrm{N}}$ value in the undamaged parts of leaves galled by E. ulmi and C. compressa showed a similar level to intact leaves (Table 1). The alterations of CF parameters were significantly correlated with the number of T. ulmi galls on the leaf blade. In our study, we recorded the highest number of six galls per leaf. Due to the increasing number of galls, $\mathrm{F}_{\mathrm{v}} / \mathrm{F}_{\mathrm{m}}, \mathrm{q}_{\mathrm{P}}$, and $\mathrm{Y}$ values in the undamaged parts of leaves were reduced (Fig. $1 A-C$ ). However, a strong positive correlation was found for the $\mathrm{q}_{\mathrm{N}}$ value and gall number (Fig. 1D).

Pigment contents: Statistical analyses showed significant differences in pigment contents in elm tissues affected by all galling aphid species (Table 2). Feeding of E. ulmi caused a significant decrease of all analysed pigment contents only in pseudogall tissue compared with intact leaves. A slight decrease in pigment contents was observed in the undamaged and damaged portions of leaves galled by $C$. compressa. A high decrease in their content, from 25-fold for Car to 36- and 37-fold for Chl $b$ and Chl $a$, respectively, was noted in gall tissues. The highest content of all analysed pigments was found in intact leaves of U. pumila. It was statistically significant, as compared to

Table 1. The Chlorophyll $a$ fluorescence characteristic $\left(\mathrm{F}_{0}-\right.$ minimal fluorescence, $\mathrm{F}_{\mathrm{v}} / \mathrm{F}_{\mathrm{m}}-$ maximum quantum yield, $\mathrm{Y}-$ effective quantum yield, qP - photochemical quenching coefficient, qN - nonphotochemical quenching coefficient,) in elm leaves infested with Colopha compressa, Eriosoma ulmi, and Tetraneura ulmi. Data are means \pm SD from 20 leaves for each combination. Means marked with the same letter in the column (for each aphid species) do not differ significantly at $p \leq 0.05$ (Tukey's HSD test for $C$. compressa and T. ulmi, Kruskal-Wallis test for E. ulmi). Leaves UP - undamaged part (without visible effect of galling) of galled leaves; Leaves AP affected part (with visible damage) of galled leaves.

\begin{tabular}{llllll}
\hline \multicolumn{1}{c}{} & $\mathrm{F}_{0}$ & $\mathrm{~F}_{\mathrm{v}} / \mathrm{F}_{\mathrm{m}}$ & $\mathrm{Y}$ & $\mathrm{qP}$ & \multicolumn{1}{c}{$\mathrm{qN}$} \\
\hline Eriosoma ulmi (L.) on Ulmus glabra & & & & \\
Intact leaves & $0.308 \pm 0.01^{\mathrm{a}}$ & $0.702 \pm 0.01^{\mathrm{a}}$ & $0.426 \pm 0.01^{\mathrm{a}}$ & $0.501 \pm 0.01^{\mathrm{a}}$ & $0.180 \pm 0.01^{\mathrm{b}}$ \\
Leaves UP & $0.251 \pm 0.01^{\mathrm{b}}$ & $0.670 \pm 0.02^{\mathrm{b}}$ & $0.393 \pm 0.01^{\mathrm{b}}$ & $0.469 \pm 0.02^{\mathrm{b}}$ & $0.183 \pm 0.01^{\mathrm{b}}$ \\
Pseudogalls & $0.169 \pm 0.01^{\mathrm{c}}$ & $0.525 \pm 0.02^{\mathrm{c}}$ & $0.340 \pm 0.01^{\mathrm{c}}$ & $0.348 \pm 0.03^{\mathrm{c}}$ & $0.201 \pm 0.01^{\mathrm{a}}$ \\
Kruskal-Wallis & $H_{(2,60)}=52.61$ & $H_{(2,60)}=47.27$ & $H_{(2,60)}=52.77$ & $H_{(2,60)}=47.25$ & $H_{(2,60)}=17.71$ \\
$p$ & 0.000 & 0.000 & 0.000 & 0.000 & 0.0001 \\
Colopha compressa & Koch.) on Ulmus laevis & & & \\
Intact leaves & $0.212 \pm 0.01^{\mathrm{a}}$ & $0.690 \pm 0.01^{\mathrm{a}}$ & $0.425 \pm 0.02^{\mathrm{a}}$ & $0.592 \pm 0.02^{\mathrm{a}}$ & $0.136 \pm 0.02^{\mathrm{b}}$ \\
Leaves UP & $0.217 \pm 0.02^{\mathrm{a}}$ & $0.693 \pm 0.01^{\mathrm{a}}$ & $0.423 \pm 0.02^{\mathrm{a}}$ & $0.595 \pm 0.02^{\mathrm{a}}$ & $0.134 \pm 0.02^{\mathrm{b}}$ \\
Leaves AP & $0.152 \pm 0.00^{\mathrm{b}}$ & $0.498 \pm 0.02^{\mathrm{b}}$ & $0.400 \pm 0.06^{\mathrm{a}}$ & $0.495 \pm 0.01^{\mathrm{b}}$ & $0.199 \pm 0.02^{\mathrm{a}}$ \\
ANOVA & $\mathrm{F}_{2,57}=162.39$ & $\mathrm{~F}_{2,57}=1318.75$ & $\mathrm{~F}_{2,57}=2.72$ & $\mathrm{~F}_{2,57}=142.05$ & $\mathrm{~F}_{2,57}=75.45$ \\
$p$ & 0.000 & 0.000 & 0.07428 & 0.000 & 0.000 \\
Tetraneura ulmi $(\mathrm{L}$.$) on Ulmus pumila$ & & & & \\
Intact leaves & $0.237 \pm 0.02^{\mathrm{a}}$ & $0.713 \pm 0.03^{\mathrm{a}}$ & $0.564 \pm 0.06^{\mathrm{a}}$ & $0.659 \pm 0.09^{\mathrm{a}}$ & $0.095 \pm 0.02^{\mathrm{c}}$ \\
Leaves UP & $0.217 \pm 0.04^{\mathrm{a}}$ & $0.579 \pm 0.08^{\mathrm{b}}$ & $0.437 \pm 0.08^{\mathrm{b}}$ & $0.521 \pm 0.11^{\mathrm{b}}$ & $0.156 \pm 0.04^{\mathrm{b}}$ \\
Leaves AP & $0.190 \pm 0.03^{\mathrm{b}}$ & $0.512 \pm 0.12^{\mathrm{c}}$ & $0.374 \pm 0.06^{\mathrm{c}}$ & $0.425 \pm 0.08^{\mathrm{c}}$ & $0.185 \pm 0.04^{\mathrm{a}}$ \\
ANOVA & $\mathrm{F}_{2,57}=11.50$ & $\mathrm{~F}_{2,57}=29.39$ & $\mathrm{~F}_{2,57}=40.05$ & $\mathrm{~F}_{2,57}=31.61$ & $\mathrm{~F}_{2,57}=40.19$ \\
$p$ & 0.000064 & 0.000 & 0.000 & 0.000 & 0.000 \\
\hline
\end{tabular}


the damaged portions of galled leaves and gall tissues of T. ulmi. Similarly as the galls, pigment contents were also lower in comparison to the undamaged portions of galled leaves (Table 2).

The differences between tissues in the Chl $a / b$ ratio were statistically confirmed only for T. ulmi (Table 2). The highest ratio of $\mathrm{Chl} a / b$ was found in the intact leaves. A gradual decline of the $\mathrm{Chl} a / b$ ratio was noted starting from

\section{Discussion}

The plant response to biotic stresses is poorly understood, mainly because its physiological effects are highly variable. The present study found that gall forming aphid infestation induced significant changes in photochemical activity of primary host trees.

Light energy, which is used for plant photosynthesis, is harvested by pigments including $\mathrm{Chl} a, \mathrm{Chl} b$, and Car, in the thylakoid membrane. Lower Chl concentration led to a decrease in leaf light absorption (Allakhverdiev 2011, Allakhverdiev et al. 2011, Yuan et al. 2018). Our study clearly showed the lowest photosynthetic pigment content in gall tissues of all analysed aphid species in comparison with intact leaves and the adjacent undamaged and damaged portions of galled leaves, indicating a possible reduction of photosynthesis in neoplastic organs. Previous studies reported that low pigment contents, Chl fluorescence, and pigment-protein complexes indicated that galls had significantly smaller light-harvesting PSI and PSII antennae than that of host leaves, and had a higher capacity for excess energy dissipation (Yang et al. 2007, Huang et al. 2011, de Oliveira et al. 2011, Castro et al. 2012, Huang et al. 2014a).

In our study, a significant decrease of $\mathrm{F}_{0}$ and pigment contents was observed only in the damaged parts of leaves galled by $T$. ulmi and in pseudogalls of E. ulmi. $\mathrm{F}_{0}$ is the primary $\mathrm{Chl}$ fluorescence yield, which measures the stability of the light-harvesting complex. It represents the fluorescence level when the PQ electron acceptor pool is fully oxidized, and it may change when exposed to stress. Generally, studies concerning of the effect of different abiotic factors on photosynthesis documented an increase of $\mathrm{F}_{0}$ values under light, drought, and salinity stress (Bączek-Kwinta et al. 2011, Guo et al. 2016). On the other hand, spider mite feeding on bean and apple leaves resulted in a decrease of the $\mathrm{F}_{0}$ value (Iatrou et al. 1995, Warabieda and Borkowska 2004). Changes of $F_{0}$ depend on the dominant factor between the energy dissipation and damage to PSII. The increase in $\mathrm{F}_{0}$ may indicate initial forms of PSII reaction centers damage, and the disorder of the light energy transfer from antenna complexes. Lower $\mathrm{F}_{0}$ values could result from increased photochemical efficiency, decreased antenna size, or a decrease in the amount of PSII per unit of leaf area (Allakhverdiev et al. 1997, Sakov et al. 2015).

The $F_{\mathrm{v}} / \mathrm{F}_{\mathrm{m}}$ decreased in the damaged and undamaged parts of leaves in $U$. pumila galled by $T$. ulmi and in the undamaged portions of galled leaves to gall tissues (Table 2). The opposite was observed in C. compressa and E. ulmi, where the highest $\mathrm{Chl} a / b$ ratio was recorded in gall tissues. However, these differences were not statistically significant. The $\mathrm{Chl} / \mathrm{Car}$ ratio in leaves affected by E. ulmi feeding and control was similar. Among aphids forming true galls, only $C$. compress $a$ caused significant differences in the $\mathrm{Chl} / \mathrm{Car}$ ratio between the tissues (Table 2).

U. glabra with E. ulmi galls. The decrease in $\mathrm{F}_{\mathrm{v}} / \mathrm{F}_{\mathrm{m}}$, according to stress factor, indicates reduced photochemical capacity and direct damage to PSII components (Maxwell and Johnson 2000, Roháček 2002, BączekKwinta et al. 2011). Contrary to our findings, Samsone et al. (2012) reported a decrease of the $\mathrm{F}_{\mathrm{v}} / \mathrm{F}_{\mathrm{m}}$ value only in the damaged leaf parts of U. glabra galled by T. ulmi, but not in E. ulmi pseudogalls. In addition, they demonstrated that the occurrence of $C$. compressa galls on $U$. laevis leaves resulted in a significant decline of the $F_{v} / F_{m}$ value in tissue below the gall, which was also confirmed in our research. Aldea et al. (2006), Fernandes et al. (2010), and Huang et al. (2014b, 2015) did not show significantly different $F_{v} / F_{m}$ values between gall-free hardwood leaves and those galled by midge flies. Similarly, the model of Populus tremuloides Michx. and midge flies (Nabity et al. 2012), as well as Aspidosperma sp. trees with psyllid and cecidomyiid galls (de Oliveira et al. 2011), did not exhibit photoinhibition in both non-galled portions of galled leaves and in gall tissues. On the other hand, the occurrence of midge Rhabdophaga rosaria (Loew) terminal rosette galls on willow induced a significant decrease of the $\mathrm{F}_{\mathrm{v}} / \mathrm{F}_{\mathrm{m}}$ value (Samsone et al. 2011). The decline in $F_{v} / F_{m}$ value, according to the stress factor, suggests the diminished photochemical capacity of PSII, alterations in the photosynthetic pigments, and also adaptative processes (Bączek-Kwinta et al. 2011, Guo et al. 2018). The occurrence of T. ulmi and E. ulmi galls resulted in a strong downregulation of the Y parameter in both damaged and undamaged parts of galled leaves. However, the presence of $C$. compressa galls did not affect the effective quantum yield of PSII photochemical conversion. High values of this parameter indicate that a large portion of photons absorbed by Chl of the PSII antenna is converted into chemical products (Kalaji et al. 2014). Ilex aquifolium L. infested by scale insects had increased $\Phi_{\text {PSII }}$ and enhanced photosynthetic electron transport (Retuerto et al. 2004). On the other hand, scale insect feeding on orchid leaves decreased (not always significantly) the effective quantum yield (Kmieć et al. 2016). In turn, galls of different arthropods (e.g. mite, midge flies, cynipid wasps) caused a significant reduction of PSII efficiency. The area of "normal" tissue with a lower effective quantum yield could be equal to the area with visible damage (Aldea et al. 2006). Nabity et al. (2012) demonstrated that the reduction of $\Phi_{\text {PSII }}$ was 

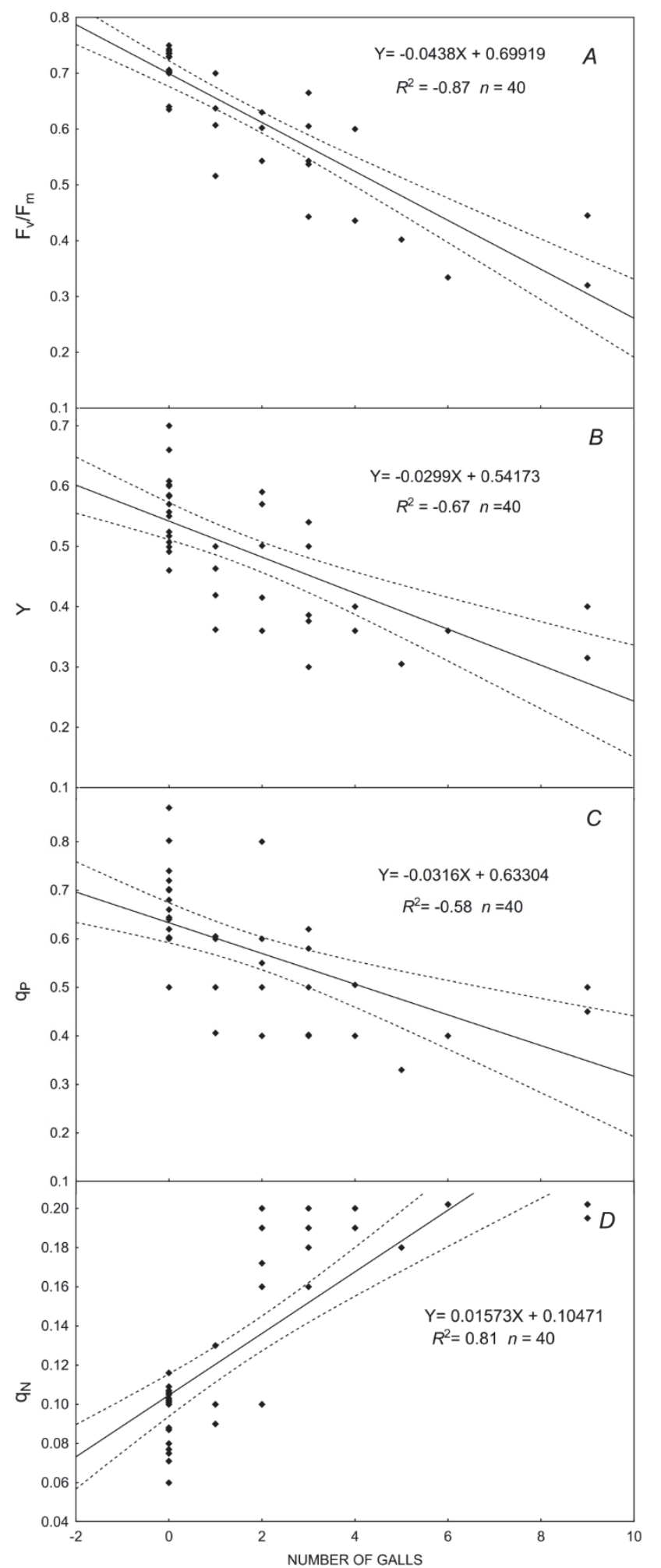

Fig. 1. The effect of Tetraneura ulmi gall number on chlorophyll fluorescence parameters: $(A) \mathrm{F}_{\mathrm{v}} / \mathrm{F}_{\mathrm{m}}-$ maximum quantum efficiency of PSII; $(B) \mathrm{Y}$ - effective quantum yield; $(C) \mathrm{qP}-$ coefficient of photochemical quenching; $(D)$ qN - coefficient of nonphotochemical quenching of Ulmus pumila leaves $(n=40)$. localized only in midge galls, however, transpiration was enhanced in the undamaged leaf tissue with galls. The $\mathrm{q}_{\mathrm{P}}$ coefficient corresponds to the portion of light energy absorbed by PSII reaction centers that are open, and is directed towards further photochemistry (Bączek-Kwinta et al. 2011, Murchie and Lawson 2013). We found a significant decrease of this coefficient values in the damaged leaf parts galled by all analysed aphid species. Galling also reduced $\mathrm{q}_{\mathrm{P}}$ in the undamaged parts of $U$. pumila and U. glabra leaves, but not in U. laevis. This was related to the high increase in nonphotochemical quenching in the damaged parts of all galled leaves and undamaged parts of leaves galled by T. ulmi. The $\mathrm{q}_{\mathrm{N}}$ coefficient reflects the activation of several nonphotochemical processes (e.g. nonradiative dissipation of the excitation energy as heat, ATP synthesis regulation, changes in thylakoid membrane $\mathrm{pH}$ or xanthophyll cycle activation). Nonphotochemical quenching plays a key role in the protection of PSII from photodamage (Ashraf and Harris 2013). The effect of abiotic (Baczek-Kwinta et al. 2011, Guo et al. 2018) and biotic (Franzen et al. 2008, Samsone et al. 2012, Golan et al. 2015) stress factors on the physiology of plants results usually in a high reduction of $\mathrm{q}_{\mathrm{P}}$ and a marked increase in $\mathrm{q}_{\mathrm{N}}$.

An imbalance between energy capture and utilization can result in an overreduction of the electron transport chain, photoinhibition, and oxidative stress caused by photoreduction of oxygen to superoxide in Mehler reaction. Formation of reactive oxygen species can damage photosynthetic apparatus and cell structure (Guo et al. 2017). Maximum quantum yield of PSII primary photochemistry increases along with elm leaf growth (Jiang et al. 2006). On the other hand, galls can be formed only on young, growing plant tissues (Wool 2004). The development of PSII complexes in newly expanding leaves may be disrupted by the galling process. Aphids, as phloem feeders, trigger a complex and interacting array of molecular and physiological responses in plants, which feedbacks to photosynthesis. They could alter water transport, stomatal aperture, as well as sucrose transport and loading (Botha et al. 2006, Nabity et al. 2009). Furthermore, plant signalling pathways, including the jasmonic acid and salicylic acid pathways, required for suppression of photosynthesis and growth, are activated upon aphid feeding (Zhou et al. 2015). The strongest inhibitory effect on photosynthesis photochemistry was found for T. ulmi galls. Aphids feeding in closed galls clearly decreased photosynthesis intensity in both damaged and undamaged parts of galled leaves. The increasing number of T. ulmi galls progressively decreased photosynthetic performance in $U$. pumila leaves. The inhibitory effect on photosynthesis photochemistry, dependent on gall density, was also characteristic for Salix sp. infested with $R$. rosaria, $S$. fragilis and Pontania vesicator (Bremi-Wolf) (Hymenoptera), Prunus padus L. with Eriophyes padi Nal. (Acari), Machilus thunbergii Sieb. 
Table 2. Pigment contents (chlorophyll $a$ and $b$, and carotenoids) in intact leaves, undamaged and damaged portions of galled leaves, and galls of Colopha compressa, Eriosoma ulmi, and Tetraneura ulmi. Values followed by the same letter in the column (for each aphid species) do not differ significantly at $p \leq 0.05$ level by Kruskal-Wallis test ( $n=5 \pm$ SD). Leaves UP - undamaged part (without visible effect of galling) of galled leaves; Leaves AP - affected part (with visible damage) of galled leaves.

\begin{tabular}{|c|c|c|c|c|c|}
\hline & $\begin{array}{l}\text { Chlorophyll } a \\
{\left[\mathrm{mg} \mathrm{g}^{-1}(\mathrm{FM})\right]}\end{array}$ & $\begin{array}{l}\text { Chlorophyll } b \\
{\left[\mathrm{mg} \mathrm{g}^{-1}(\mathrm{FM})\right]}\end{array}$ & $\begin{array}{l}\text { Carotenoids } \\
{\left[\mathrm{mg} \mathrm{g}^{-1}(\mathrm{FM})\right]}\end{array}$ & Chl $a / b$ ratio & $\mathrm{Chl} /$ Car ratio \\
\hline \multicolumn{6}{|c|}{ Eriosoma ulmi (L.) on Ulmus glabra } \\
\hline Control leaves & $3.236 \pm 0.33^{\mathrm{a}}$ & $0.846 \pm 0.04^{\mathrm{a}}$ & $0.600 \pm 0.02^{\mathrm{a}}$ & $3.8^{\mathrm{a}}$ & $6.8^{\mathrm{a}}$ \\
\hline Leaves UP & $3.194 \pm 0.06^{\mathrm{a}}$ & $0.860 \pm 0.03^{\mathrm{a}}$ & $0.614 \pm 0.04^{\mathrm{a}}$ & $3.7^{\mathrm{a}}$ & $6.6^{\mathrm{a}}$ \\
\hline Pseudogalls & $2.626 \pm 0.03^{\mathrm{b}}$ & $0.458 \pm 0.05^{\mathrm{b}}$ & $0.496 \pm 0.02^{\mathrm{b}}$ & $5.8^{\mathrm{a}}$ & $6.2^{\mathrm{a}}$ \\
\hline$H_{(2,15)}$ & 9.500 & 9.589 & 9.641 & 3.440 & 3.260 \\
\hline$p$ & 0.0087 & 0.0083 & 0.0081 & 0.1791 & 0.1959 \\
\hline \multicolumn{6}{|c|}{ Colopha compressa (Koch.) on Ulmus laevis } \\
\hline Control leaves & $2.942 \pm 0.02^{\mathrm{a}}$ & $0.656 \pm 0.02^{\mathrm{a}}$ & $0.690 \pm 0.02^{\mathrm{a}}$ & $4.5^{\mathrm{a}}$ & $5.2^{\mathrm{ab}}$ \\
\hline Leaves UP & $2.926 \pm 0.02^{\mathrm{a}}$ & $0.638 \pm 0.02^{\mathrm{a}}$ & $0.646 \pm 0.01^{\mathrm{ab}}$ & $4.6^{\mathrm{a}}$ & $5.5^{\mathrm{a}}$ \\
\hline Leaves AP & $2.336 \pm 0.02^{\mathrm{ab}}$ & $0.608 \pm 0.01^{\mathrm{ab}}$ & $0.644 \pm 0.02^{\mathrm{ab}}$ & $3.8^{\text {a }}$ & $4.6^{\mathrm{b}}$ \\
\hline Galls & $0.080 \pm 0.01^{\mathrm{b}}$ & $0.018 \pm 0.01^{\mathrm{b}}$ & $0.028 \pm 0.01^{\mathrm{b}}$ & $5.2^{\mathrm{a}}$ & $3.8^{\mathrm{b}}$ \\
\hline$H_{(3,20)}$ & 16.394 & 15.582 & 16.039 & 8.189 & 11.900 \\
\hline$p$ & 0.0009 & 0.014 & 0.011 & 0.0423 & 0.0077 \\
\hline \multicolumn{6}{|c|}{ Tetraneura ulmi (L.) on Ulmus pumila } \\
\hline Control leaves & $2.626 \pm 0.03^{\mathrm{a}}$ & $0.458 \pm 0.05^{\mathrm{a}}$ & $0.496 \pm 0.02^{\mathrm{a}}$ & $5.8^{\mathrm{a}}$ & $6.2^{\mathrm{a}}$ \\
\hline Leaves UP & $1.776 \pm 0.02^{\mathrm{ab}}$ & $0.352 \pm 0.02^{\mathrm{ab}}$ & $0.418 \pm 0.03^{\mathrm{ab}}$ & $5.1^{\mathrm{ab}}$ & $5.1^{\mathrm{a}}$ \\
\hline Leaves AP & $0.940 \pm 0.15^{\mathrm{bc}}$ & $0.210 \pm 0.04^{\mathrm{bc}}$ & $0.222 \pm 0.04^{\mathrm{bc}}$ & $4.5^{\mathrm{b}}$ & $5.2^{\mathrm{a}}$ \\
\hline Galls & $0.214 \pm 0.03^{\mathrm{c}}$ & $0.060 \pm 0.02^{\mathrm{c}}$ & $0.050 \pm 0.02^{\mathrm{c}}$ & $3.9^{\mathrm{b}}$ & $6.2^{\mathrm{a}}$ \\
\hline$H_{(3,20)}$ & 17.857 & 17.871 & 17.857 & 12.303 & 6.406 \\
\hline$p$ & 0.0005 & 0.0005 & 0.0050 & 0.0065 & 0.0935 \\
\hline
\end{tabular}

with Daphnephila taiwanensis (Tokuda, Yang \& Yukawa) and D. sueyenae (Tokuda, Yang \& Yukawa) (Diptera) (Samsone et al. 2011, 2012; Huang et al. 2014b).

Leaf roll pseudogalls of E. ulmi were distinguished by visible chlorosis, similarly to the area around the stalks of T. ulmi galls. This might be explained by a significant reduction in Chl $a$ and $b$ as well as Car contents observed in those areas, as compared to intact leaves. Chlorosis of Eucalyptus obliqua (L'Herit.) leaves with a significant decrease in pigment content was induced by the feeding of gall-forming psyllid (Khattab and Khattab 2005). On the other hand, we did not observe a significant reduction in pigment content in galled leaves both above and below the galls of $C$. compressa, despite slight discoloration of the leaf blade. However, Samsone et al. (2007) showed a significantly lower $\mathrm{Chl}$ content (indicated by SPAD measurements) in affected tissue compared to galled leaf above the gall and intact leaves of $U$. laevis. Variation in the $\mathrm{Chl} a / b$ and $\mathrm{Chl} / \mathrm{Car}$ ratios is used as an indicator of stress and damage to the photosynthetic apparatus (Ni et al. 2002, Heng-Moss et al. 2003). Despite the reductions in Chl $a$ and $b$ and Car contents, we did not observe significant differences in the $\mathrm{Chl} a / b$ ratio. Heng-Moss et al. (2003) reported a similar pattern for $D$. noxia feeding. However, Castro et al. (2012) and Gailite et al. (2005) showed a significant decrease in the $\mathrm{Chl} a / b$ ratio in gall tissues in comparison with non-galled leaves, also in the case of C. compressa, E. ulmi, and T. ulmi. We did not find differences between tissues in the $\mathrm{Chl} / \mathrm{Car}$ ratio for $E$. ulmi and T. ulmi galling, despite visible changes in leaf appearance. A similar relationship was observed in the D. noxia and wheat model (Ni et al. 2002). In galls of C. compressa and tissue below the gall, the Chl/Car ratio was significantly lower compared to the undamaged portions of galled and intact leaves. This may be the result of reddish/yellowish coloration of cockscomb-shaped galls. The low $\mathrm{Chl} / \mathrm{Car}$ ratio was also reported in midge galls on Litsea acuminate (Blume) (Huang et al. 2015).

In conclusion, we discovered the significant effect of galling on photosynthesis photochemistry of the primary host for all analysed aphid species. The strongest suppression of photosynthesis and pigment contents was revealed in T. ulmi and U. pumila interactions. No clear differences between the impact of open and closed galls were found. The suppression of photosynthesis in different parts of galled leaves was partly associated with the reduction of the pigment content. The galls varied in a shape, colour, and location on the leaf, but all were characterised by pigment content deficiency, indicating that the photosynthetic capacity must have been lower in galls or that there was no photosynthesis. 
Open Access This article is distributed under the terms of the Creative Commons Attribution License which permits any use, distribution, and reproduction in any medium, provided the original author(s) and the source are credited.

\section{References}

Aldea M., Hamilton J.G., Resti J.P. et al.: Comparison of photosynthetic damage from arthropod herbivory and pathogen infection in understory hardwood saplings. - Oecologia 149: 221-232, 2006.

Allakhverdiev S.I., Klimov V.V., Carpentier R.: Evidence for the involvement of cyclic electron transport in the protection of photosystem II against photoinhibition: Influence of a new phenolic compound. - Biochemistry 36: 4149-4154, 1997.

Allakhverdiev S.I., Tsuchiya T., Watabe K. et al.: Redox potentials of primary electron acceptor quinone molecule $\left(\mathrm{Q}_{\mathrm{A}}\right)$ - and conserved energetics of photosystem II in cyanobacteria with chlorophyll $a$ and chlorophyll $d$. - P. Natl. Acad. Sci. USA 108: 8054-8058, 2011.

Allakhverdiev S.I.: Recent progress in the studies of structure and function of photosystem II. - J. Photoch. Photobio. B 104: 1-8, 2011.

Álvarez R., González-Sierra S., Candelas A. et al.: Histological study of galls induced by aphids on leaves of Ulmus minor: Tetraneura ulmi induces globose galls and Eriosoma ulmi induces pseudogalls. - Arthropod-Plant Inte. 7: 643-650, 2013.

Ashraf M., Harris P.J.C.: Photosynthesis under stressful environments: An overview. - Photosynthetica 51: 163-190, 2013.

Bączek-Kwinta R., Kozieł A., Seidler-Łożykowska K.: Are the fluorescence parameters of German chamomile leaves the first indicators of the anthodia yield in drought conditions? Photosynthetica 49: 87-97, 2011.

Blackman R.L., Eastop V.F.: Aphids of the World's Plants: An Online Identification and Information Guide. Available online: http://www.aphidsonworldsplants.info (Accessed 19 May 2017).

Botha A.M., Lacock L., van Niekerk C. et al.: Is photosynthetic transcriptional regulation in Triticum aestivum $\mathrm{L} . \mathrm{cv}$. 'TungelaDN' a contributing factor for tolerance to Diuraphis noxia (Homoptera: Aphididae)? - Plant Cell Rep. 25: 41-54, 2006.

Castro A.C., Oliveira D.C., Moreira A.S.F.P. et al.: Source-sink relationship and photosynthesis in the horn-shaped gall and its host plant Copaifera langsdorffii Desf. (Fabaceae). - South Afr. J. Bot. 83: 121-126, 2012.

de Oliveira D.C., Isaias R.M., Moreira A.S. et al.: Is the oxidative stress caused by Aspidosperma spp. galls capable of altering leaf photosynthesis? - Plant Sci. 180: 489-495, 2011.

El-Akkad S.S.: Biochemical changes induced in Populus nigra leaves by galling aphid Pemphigous populi. - Int. J. Agric. Biol. 6: 650-664, 2004

Elzinga D.A., De Vos M., Jander G.: Suppression of plant defenses by a Myzus persicae (Green Peach Aphid) salivary effector protein. - Mol. Plant Microbe. In. 27: 747-756, 2014.

Fernandes G.W., Coelho M.S., Lüttge U.: Photosynthetic efficiency of Clusia arrudae leaf tissue with and without Cecidomyiidae galls. - Braz. J. Biol. 70: 723-728, 2010.

Franzen L.D., Gutsche A.R., Heng-Moss T.M. et al.: Physiological responses of wheat and barley to Russian wheat aphid, Diuraphis noxia (Mordvilko) and bird cherry-oat aphid, Rhopalosiphym padi (L.) (Hemiptera: Aphididae). - ArthopodPlant Inte. 2: 227-235, 2008.

Gailite A., Andersone U., Ievinsh G.: Arthropod-induced neo- plastic formations on trees change photosynthetic pigment levels and oxidative enzyme activities. - J. Plant Interact. 1: 6167, 2005.

Golan K., Rubinowska K., Kmieć K. et al.: Impact of scale insect infestation on the content of photosynthetic pigments and chlorophyll fluorescence in two host plant species. Arthropod-Plant Inter. 9: 55-65, 2015.

Guo Y.Y., Yu H.Y., Kong D.S. et al.: Effects of drought stress on growth and chlorophyll fluorescence of Lycium ruthenicum Murr. seedlings. - Photosynthetica 54: 524-531, 2016.

Guo Y.Y., Tian S.S., Liu S.S. et al.: Energy dissipation and antioxidant enzyme system protect photosystem II of sweet sorghum under drought stress. - Photosynthetica 56: 861-872, 2018.

Harris M.O., Freeman T.P., Moore J. A. et al.: H-Gene-Mediated resistance to Hessian fly exhibits features of penetration resistance to fungi. - Phytopathology 100: 279-289, 2010.

Heng-Moss T.M., Ni X., Macedo T. et al.: Comparison of chlorophyll and carotenoid concentrations among Russian wheat aphid (Homoptera: Aphididae) - infested wheat isolines. - J. Econ. Entomol. 96: 475-481, 2003.

Huang M.Y., Chou H.M., Chang Y.T. et al:: The number of cecidomyiid insect galls affects the photosynthesis of Machilus thunbergii host leaves. - J. Asia-Pac. Entomol. 17: 151-154, 2014b.

Huang M.Y., Huang W.D., Chou H.M. et al.: Herbivorous insects alter the chlorophyll metabolism of galls on host plants. - J. Asia-Pac. Entomol. 17: 431-434, 2014a.

Huang M.Y., Huang W.D., Chou H.M. et al.: Structural, biochemical, and physiological characterization of photosynthesis in leaf-derived cup-shaped galls on Litsea acuminata. - BMC Plant Biol. 15: 61-73, 2015.

Huang M.Y., Lin K.H., Yang M.M. et al.: Chlorophyll fluorescence, spectral properties, and pigment composition of galls on leaves of Machilus thunbergii. - Int. J. Plant Sci. 172: 323-329, 2011.

Iatrou G., Cook C.M., Stamou G. et al.: Chlorophyll fluorescence and leaf chlorophyll content of bean leaves injured by spider mites (Acari: Tetranychidae). - Exp. Appl. Acarol. 19: 581591, 1995.

Jiang C.D., Jiang G.M., Wang X. et al.: Increased photosynthetic activities and thermostability of photosystem II with leaf development of elm seedlings (Ulmus pumila) probed by the fast fluorescence rise OJIP. - Environ. Exp. Bot. 58: 261-268, 2006.

Kalaji H.M., Schansker G., Ladle R.J. et al.: Frequently asked questions about in vivo chlorophyll fluorescence: practical issues. - Photosynth. Res. 122: 121-158, 2014.

Khattab H., Khattab I.: Responses of Eucalypt trees to the insect feeding (gall-forming psyllid). - Int. J. Agric. Biol. 7: 979-984, 2005.

Kmieć K., Kot I., Sytykiewicz H. et al.: Aphids' galls - damage or decorative value of host plants? - Scientific Proceedings of the 5th International Scientific Horticulture Conference, Nitra, Slovakia 21-23 September. Pp. 44-48, 2016.

Kmieć K., Kot I.: [Occurence of aphids from Eriosomatinae subfamily on elms in the green area in Lublin.] - Ann. Univ. 
Mariae Curie-Skłodowska, 20: 7-13, 2010. [In Polish]

Kmieć K., Kot I.: Tetraneura ulmi (L.) (Hemiptera, Eriosomatinae) on elm as its primary host. - Aphids Other Hemipter. Ins. 13: 145-149, 2007.

Kmieć K., Sempruch C., Chrzanowski G. et al.: The effect of Tetraneura ulmi $\mathrm{L}$. galling process on the activity of amino acid decarboxylases and the content of biogenic amines in Siberian elm tissues. - Bull. Entomol. Res. 18: 1-8, 2017.

Kot I., Kmieć K.: Galls induced by insects on oaks and elms in the Lublin region, Poland. - Electron. J. Pol. Agric. Univ. 16: 3, 2013.

Larson K.C., Whitham T.G.: Competition between gall aphids and natural plant sinks: plant architecture affects resistance to galling. - Oecologia 109: 575-582, 1997.

Larson K.C., Whitham T.G.: Manipulation of food resources by a gall-forming aphid: the physiology of sink-source interactions. - Oecologia 88: 15-21, 1991.

Larson K.C.: The impact of two gall-forming arthropods on the photosynthetic rates of their hosts. - Oecologia 115: 161-166, 1998.

Lichtenthaler H.K., Wellburn A.R.: Determinations of total carotenoids and chlorophylls a and $\mathrm{b}$ of leaf extracts in different solvents. - Biochem. Soc. T. 11: 591-592, 1983.

Maxwell K., Johnson G.N.: Chlorophyll fluorescence - a practical guide. - J. Exp. Bot. 51: 659-668, 2000.

Murchie E.H., Lawson T.: Chlorophyll fluorescence analysis: a guide to good practice and understanding some new applications. - J. Exp. Bot. 64: 3983-3998, 2013.

Nabity P.D., Hillstrom M.L., Lindroth R.L. et al.: Elevated $\mathrm{CO}_{2}$ interacts with herbivory to alter chlorophyll fluorescence and leaf temperature in Betula papyrifera and Populus tremuloides. - Oecologia 169: 905-913, 2012.

Nabity P.D., Zavala J.A., DeLucia E.H.: Indirect suppression of photosynthesis on individual leaves by arthropod herbivory. Ann. Bot.-London 103: 655-663, 2009.

Netto A.T., Campostrini E., de Oliveira J.G. et al.: Photosynthetic pigments, nitrogen, chlorophyll $a$ fluorescence and SPAD-502 readings in coffee leaves. - Sci. Hortic.-Amsterdam 104: 199-209, 2005.

Ni X., Quisenberry S.S., Heng-Moss T. et al.: Dynamic change in photosynthetic pigments and chlorophyll degradation elicited by cereal aphid feeding. - Entomol. Exp. Appl. 105: 43-53, 2002.

Retuerto R., Fernandez-Lema B., Rodriguez-Roiloa S. et al.: Increased photosynthetic performance in holly trees infested by scale insects. - Funct. Ecol. 18: 664-669, 2004.

Roháček K.: Chlorophyll fluorescence parameters: the definitions, photosynthetic meaning, and mutual relationship. Photosynthetica 40: 13-29, 2002.

Sakov V.S., Krivchenko A.I., Rozengart E.V. et al.: Successes in application of pulse - amplitude modulated fluorescence. - In: Sakov V.S., Krivchenko A.I., Rozengart E.V. et al. (ed.): Derivative Spectrophotometry and PAM - Fluorescence in Comparative Biochemistry. Pp. 47-176. Springer International Publ., Cham 2015.

Samsone I., Andersone U., Ievinsh G.: Gall midge Rhabdophaga rosaria - induced rosette galls on Salix: morphology, photochemistry of photosynthesis and defense enzyme activity. - Environ. Exp. Biol. 9: 29-36, 2011.

Samsone I., Andersone U., Ievinsh G.: Variable effect of arthropod-induced galls on photochemistry of photosynthesis, oxidative enzyme activity and ethylene production in tree leaf tissues. - Environ. Exp. Biol. 10: 15-26, 2012.

Samsone I., Andersone U., Vikmane M. et al.: Nondestructive methods in plant biology: an accurate measurement of chlorophyll content by a chlorophyll meter. - Acta Univ. Latv. 723: 145-154, 2007.

Schreiber U., Neubauer C., Schliwa U.: PAM fluorometer based on medium-frequency pulsed Xe-flash measuring light: a highly sensitive new tool in basic and applied photosynthesis research. - Photosynth Res. 36: 65-72, 1992.

Statistica StatSoft Inc.: Data Analysis Software System. Version 13.1. Available online at www.ststsoft.com, 2016.

Suzuki D.K., Fukushi Y., Akimoto S.: Do aphid galls provide good nutrients for the aphids?: Comparisons of amino acid concentrations in galls among Tetraneura species (Aphididae: Eriosomatinae). - Arthropod-Plant Inte. 3: 241-247, 2009.

Urban J.: Bionomics and harmfulness of Tetraneura ulmi (L.) (Aphidinea, Pemphigidae) in elms. - J. Forest Sci. 49: 159-181, 2003.

Warabieda W., Borkowska B.: Chlorophyll $a$ fluorescence as a diagnostic tool for assessment of apple resistance against twospotted spider mite (Tetranychus urticae Koch.). - Electron. J. Pol. Agric. Univ. 7: 1, 2004.

Wojciechowski W., Depa Ł., Kanturski M. et al.: An annotated checklist of the Aphids (Hemiptera: Aphidomorpha) of Poland. - Pol. J. Entomol. 84: 83-420, 2015.

Wool D.: Galling aphids: specialization, biological complexity, and variation. - Annu. Rev. Entomol. 49: 175-192, 2004.

Yang C.M., Yang M.M., Huang M.Y. et al.: Life time deficiency of photosynthetic pigment-protein complexes $\mathrm{CP} 1, \mathrm{~A} 1, \mathrm{AB} 1$, and $\mathrm{AB} 1$ in two cecidomyiid galls derived from Machilus thunbergii leaves. - Photosynthetica 45: 589-593, 2007.

Yuan R.N., Shu S., Guo S.R. et al.: The positive roles of exogenous putrescine on chlorophyll metabolism and xanthophyll cycle in salt-stressed cucumber seedlings. Photosynthetica 56: 557-566, 2018.

Zhou S., Lou Y.R., Tzin V. et al.: Alteration of plant primary metabolism in response to insect herbivory. - Plant Physiol. 169: 1488-1498, 2015. 